\title{
POURFOUR DU PETIT'S EXPERIMENTS ON THE ORIGIN OF THE SYMPATHETIC NERVE
}

\author{
by
}

A. E. BEST

POURFOUR DU PETIT is of interest in the history of neuroanatomy for his observations and controlled experiments which led to the correction of the earlier view that the 'intercostal nerve' is of cranial origin. The so-called intercostal nerve was the name which had been given by Thomas Willis to the sympathetic chain. This, of course, is one of the two divisions of the autonomic system which innervates smooth muscle and glandular tissue.

It has now been known for many years that the preganglionic fibres of the sympathetic chain have their superficial origin in thoracic and lumbar segments of the spinal cord, and that it is only as an extension from the thoracic chain that sympathetic branches find their way into the neck and structures of the head. Stretching downwards from its uppermost ganglion in the neck the sympathetic trunk, when open to view, resembles a skein of loose crochet-work. On entering the thorax it veers backwards to follow the spinal curve, but as it descends behind the pleura, it generally inclines forwards from the heads of the ribs on the sides of the vertebrae, ganglia being studded at intervals along its length. Morgagni's early eighteenthcentury engravings which depict the draping of the sympathetic nerve down the back of the empty thorax conform well to this description. ${ }^{1}$ In relation to the ribs, Willis's name 'intercostal' was not appropriate; it was a transcostal nerve. His mistaken notion, however, about the cranial origin of this nerve, was, as we shall presently see, pardonable enough.

As we are informed in any modern textbook on anatomy, all the cranial nerves except the first, second and eighth receive postganglionic fibres, either directly or indirectly, from the sympathetic trunk. Fibres from the side of the superior cervical ganglion of the sympathetic trunk extend directly to the hypoglossal nerve and to the inferior ganglion of the vagus nerve. Also a short ascending jugular nerve divides into twigs which reach the superior ganglion of the vagus and the inferior ganglion of the glossopharyngeal nerve. Other cranial nerves-the oculomotor, the trochlear, the abducent, and the ophthalmic division of the trigeminal-receive sympathetic twigs indirectly in the cavernous sinus from the internal carotid plexus, the net-like ramification round the internal carotid artery which is formed from the postganglionic branch of the upper pole of the superior cervical ganglion. The fundamental error of such earlier anatomists as Willis and Vieussens was in describing these fibres between the carotid plexus and certain cranial nerves as emerging from them, rather than as verging into their branches and sharing common sheaths. In its grosser form, this misunderstanding was corrected by Pourfour du Petit.

François Pourfour du Petit-to be carefully distinguished from his contemporary

1 J. B. Morgagni, Adversaria anatomica omnia, Padua, 1719, Bk. 5 ('Dissertatio'), facing p. 121. 


\section{Pourfour du Petit's Experiments on the Origin of the Sympathetic Nerve}

and fellow surgeon, Jean Louis Petit ${ }^{2}$-was born in Paris in 1664 and he died there in $1741 .^{3}$ His earlier, classical education appears to have been almost a failure, ${ }^{4}$ though he showed some flair for philosophy and for physical science, and after a period of travel and private study under a cultivated scientific amateur whom he had met at La Rochelle, he matriculated at the University of Montpellier where he studied medicine and some general science. He obtained a medical degree at Montpellier in 1690, but before practising, however, he spent a further period of study in Paris. His studies included anatomy, botany and chemistry under such famous teachers as Duverney, Tournefort and Lémery, and surgery in the Hôpital de la Charité. Most of his subsequent medical practice was as a physician in the armies of Louis XIV, in which he obtained appointments during the two major campaigns that terminated in the Treaties of Ryswick (1693) and of Utrecht (1713). It was during the latter campaign that he published his small but important work, Lettres du Médecin. On finally leaving the army he settled down and established himself professionally in Paris. His interest in scientific medicine led to his election in 1722 as a member of the Académie Royale des Sciences, and thereafter he specialized almost exclusively in diseases and surgery of the eye, in which he was highly successful, not only as a skilful operator on cataract, but as a resourceful designer of ophthalmic instruments.

We have already indicated that what du Petit had to say on the intercostal nerve was a reaction to the views of the two great seventeenth-century neuroanatomists, Thomas Willis (1621-1675) and Raymond Vieussens (1641-1716). Although the enumeration of the cranial nerves as consisting of twelve pairs, the convention with which we are now familiar, was not finally given until the time of Sömmerring later in the eighteenth century, ${ }^{5}$ the classification suggested by Lower and adopted by Willis and Vieussens ${ }^{6}$ had gone a long way towards providing a rational scheme for teaching and study. Some anatomists still preferred the older classification, ${ }^{7}$ though the one generally used in the beginning of the eighteenth century was that given by Willis. This was as follows:

Ordinal number of cranial nerve
1
2
3
4
5
6
7
8
9
10

Identification
olfactory
optic
oculomotor
trochlear
trigeminal
abducent
facial and auditory
glossopharyngeal, vagus and accessory
hypoglossal
suboccipital

2 We shall adopt as the abbreviated form of Pourfour du Petit that used in French biographical encyclopaedias-du Petit.

Biographie Universelle (Michaud), 1843, vol. 32, p. 581(ii).

- . . parceque sa mémoire était très-ingrate'. (loc. cit.)

A. T. Rasmussen, Some Trends in Neuroanatomy, Dubuque, U.S.A., 1947, p.17.

- Ibid., p. 12.

'See, for instance, I. Diemerbroek, Opera omnia, anatomica et medica, Utrecht, 1685, p. 361. 


\section{A. E. Best}

The broad classification of the first six is, of course, the one still used today. Two cranial nerves, namely the fifth and the sixth, are especially relevant to this paper.

By the third quarter of the seventeenth century it was generally recognized that the roots, motor and sensory, of the fifth cranial nerve emerged from the sides of the pons, and that the fibres, collected into two 'trunks', mounted the 'petrosal bone' and entered the sack-like receptacle in the depression at the side of the Turkish saddle. ${ }^{8}$ Here, Willis stated, it split up into its great branches. Rather more accurately, Vieussens marked out these divisions as issuing from a 'prominent ganglion', which was formed at the outer side of the 'saddle' from the two 'trunks' [roots] of this fifth nerve. It is not clear at this stage whether anatomists were treating the division of the fifth cranial nerve as twofold or as threefold [trigeminal]. Willis's diagram depicted only a 'first' and a 'second' great division, and though his terminology was rather inconsistent in the chapter to which this diagram referred, it would seem that he regarded the principal division as a twofold one. ${ }^{\circ}$ Vieussens spoke of the fifth nerve as dividing into two greater branches, the posterior and anterior, near to the ganglion. ${ }^{10}$ This would seem to imply a minor branch, or branches, though his diagram, engraved by Beaudeau, is clearly that of a twofold division. ${ }^{11}$ Henry Ridley, who described the ganglion as propagating several branches, each of which emerged from the skull by one of three foramina, would appear to be the first to treat the division of the fifth nerve as trigeminal. ${ }^{12}$

Although, in describing the fifth cranial nerve, Vieussens kept fairly close to the account of Willis, there are certain minor, and occasionally rather confusing differences between them. For instance, Willis appeared to treat the (modern) frontal nerve in detachment from, and not as a division of the ophthalmic trunk. We propose, therefore, to use Vieussens' description as the more consistent and straightforward account of the fifth cranial nerve, and to refer to Willis as important differences arise.

Vieussens described the 'anterior division' of the fifth cranial nerve as leaving the receptacle on each side of the 'saddle' [Turkish saddle] and dividing into two minor

R. Vieussens, Neurographia universalis, Leyden, 1685, p. 169, 'Ista nervorum conjugatio, quam ... quintam numeramus, truncis amplis e lateribus processus a cerebello ad medullam oblongatam oritur ... Haec pluribus quidem fibris constat, quarum aliae sunt molles, aliae duriores, et aliae ab aliis facile separari possunt, licet simul colligatae sint, adeo ut uterque illius caudex prope originem nihil aliud sit, quam fasciculus plurium nervulorum, qui in diversas partes inseruntur, ac in quibusdam sensus tantum, et in reliquis sensus, motusque munia exequuntur ... Quintae conjugationis nervos interdum, juxta ipsam originem in duos truncos divisos, crassa meninx investit, statim atque os petrosum utrinque superscanderunt, eosque in foveola velut sacculo recondit, quem ipsamet in utroque calvariae latere, pone receptacula sellae equinae lateribus apposita efformat, ubi insignem in plexum ganglioformem abeunt ....

- T. Willis, Cerebri anatome, cui accessit nervorum descriptio et usus, London, 1664, p. 153, 'Statim .... magnus iste paris quinti nervus in duos ramos insignes dividitur . . ..

io $R$. Vieussens, op. cit., p. 170, 'Uterque nervus quintae conjugationis circa plexum ganglioformem, in binos ramos majores, anteriorem nempe, et posteriorem dirimitur . . . .

11 See fig. 1, Vieussens' Diagram of the fifth and sixth cranial Nerves.

12 H. Ridley, The Anatomy of the Brain, London, 1695, p. 147. After describing how the fifth nerve, made up of many fibres, arises from the uppermost part of the 'annular process', Ridley continues: 'This nerve, after having climbed over the inner process of the os petrosum into a kind of cavity made of a duplicature of the dura mater in that place, immediately swells into a kind of thickness, called a ganglion, from whence several branches are propagated, lying between the dura mater and the cranium, on each side of the sella Turcica.... going out of the skull at three several places, its superior small branch at the second hole with the third and fourth pair of nerves, its inferior smaller branch at the third hole, and its posterior or largest branch at the fifth.' 


\section{Pourfour du Petit's Experiments on the Origin of the Sympathetic Nerve}

branches, namely the 'upper minor branch' and the 'lower minor branch' ${ }^{13}$ Of these, the 'upper minor branch', which was also referred to as the ophthalmic nerve, was described as first entering the orbit of the eye and there splitting up into three branchlets. These corresponded, of course, to the familiar classification for the three divisions of the ophthalmic nerve. It is Vieussens' account of this ophthalmic nerve which probably had an important bearing on the later researches of du Petit.

The first of these ophthalmic divisions, the modern frontal nerve, after projecting an offset [supratrochlear nerve], ${ }^{14}$ was described as leaving the ocular orbit by a 'special foramen' [supra-orbital notch] to project fibrils to the muscles of the forehead and to the skin of the frontal part of the head. Meanwhile the offset from this branch, that it, the more modern supratrochlear nerve, was said to 'direct its fibrils to the lacrimal gland [lacrimal sac?] adjoining the eye-ball, to the levator muscles of the nose, to the eyelid(s), and to the orbicular muscle'. In the case of 'brutes', Willis explained, another extension of this offset was directed to the muscle with which these animals blink [nictitating membrane]. ${ }^{15}$ Evidently some of the ramifications ascribed to this nerve, which can only be identified as the supratrochlear, really belonged to the infratrochlear, but we may waive such mistakes as unimportant for our purpose here. In any case, it can hardly be emphasized too strongly that probably for Vieussens and certainly for Willis this description of the nerves was based upon a comparative study of more than one animal.

The second division of the ophthalmic nerve, that is, the one which is now referred to as the nasociliary nerve, was described by Vieussens as dividing into two offsets, ${ }^{16}$ and by Willis as dividing into four or five branchlets, ${ }^{17}$ the smaller and more external of Vieussens' two divisions corresponding, apparently, to the first and outermost of two slender twigs mentioned by Willis. These minor divisions have considerable bearing on du Petit's paper on the 'intercostal nerve'. Vieussens, in describing the branches or divisions of the nasociliary nerve, wrote that the 'smaller of them, and the one more external with respect to the minor canthus of the eye, projects several small fibres, and these, along with certain small fibres [parasympathetic root?] which were projected from the third cranial nerve, form, as it were, a plexus [ciliary ganglion],

\footnotetext{
12 R. Vieussens, op. cit., p. 170, 'Anterior . . . . receptaculum sellae equinae lateri appositum ingreditur ... Et cum primum ex ipso emersit in duos ferme aequales ramos minores, superiorem scilicet, et inferiorem dividitur.

Ramus minor superior oculi orbitam ingressus, statim in tres ramulos finditur, quorum primus, uno emisso surculo, qui adnatae oculi tunicae, glandulae lachrymali, musculis nasum sursum moventibus, palpebris, et orbiculari ipsarum musculo fibrillas suas impertit, musculum palpebram superiorem sursum trahentem superscandit, et ulterius progrediendo ex orbita interdum per foramen peculiare, et ut plurimum per incisuram ossis frontis emergit, ac demum in plures propagines divisus non modo frontis musculis fibrillas largitur, sed etiam illius, sicut et anticae capitis regionis exterioribus tegumentis prospicit.'

14 Modern terms are indicated in square brackets.

${ }^{15} \mathrm{~T}$. Willis, op. cit. p. 154, 'Alter autem hujus divisionis ramus in musculum quo bruta nictitant impenditur.'

i6 R. Vieussens, op. cit., p. 170, 'Secundus ramulus nervo pathetico necnon primo nervi oculum moventis ramulis ramulo substratus, in duas propagines dividitur.....'

${ }_{17} \mathrm{~T}$. Willis, op. cit., p. 154, 'Ramus secundus quinti paris ophthalmicus in quatuor vel quinque surculos dividitur, qui omnes supra musculos oculi pergentes, perque glandulas ejus aliquatenus trajecti, fere toti in palpebras absumuntur, nisi quod in transitu duas exiles propagines dimittunt, qui tunicam scleroticam paulo infra tendines musculorum subeunt, ac ad uveam pertingunt .....
} 


\section{A. E. Best}

which is attached to the trunk of, and faces the outer membranes of the optic nerve.'18 He then went on to describe how small fibres [short ciliaries] emerged from this plexus, some of which entered the 'depressor and adducent muscles of the eye, whilst others actually penetrated the rear part of the sclerotic membrane'. Here, he maintained, some of these fibres ended, though others went forwards 'within the uvea, so that, as by an involuntary spasm of the eye, the pupil, which lies symmetrically in the front of the eye, may be made to dilate to an abnormal extent'.

Vieussens then described how the larger of those two nasociliary divisions-the main trunk of this nerve-after crossing over the optic nerve to the inner side of the eye, divided into four twigs, ${ }^{19}$ these being the remainder of those minor divisions identified and mentioned by Willis. One of these twigs [long ciliary] was described as going out to the sclerotic membrane at the back of the eyeball. Another twig, by leaving the orbit close to the crista galli, penetrated the 'thick membrane' [dura mater], and passed out of the skull through one of the foramina cut in the cribiform bone, distributing fibrils [presumably as the internal nasal branch of the anterior ethmoidal nerve] through the membrane covering the inside of the nose. ${ }^{20}$ Finally, the other two twigs, of which one was probably the infratrochlear nerve, were said to distribute fibrils to the eyelid and orbicular muscle, and to the outer skin and levator muscles of the nose. ${ }^{21}$

Vieussens' third division of the ophthalmic nerve [lacrimal nerve], which was treated by Willis, apparently, in isolation from the ophthalmic nerve, was described as 'lying below the abducent muscle, extending to the outer canthus of the eye, and terminating in the "innominate gland" [lacrimal gland]'.22

Other branches of the fifth nerve are hardly relevant to this paper. The 'second branch' [maxillary nerve] was described as leaving the cranium by the 'third foramen' [foramen rotundum], and projecting three branchlets and one twig. This latter, which was said to enter the orbit, to leave by a 'minute foramen', and then to supply the cheeks and muscles of the upper lip, was certainly the slender zygomatic nerve. One of the branchlets, which apparently entered the fold of bone in the bed of the orbit, and emerged through the 'special foramen' to divide into three or four shoots supplying the facial skin, upper lip and nasal parts, was obviously the infraorbital nerve.

\footnotetext{
${ }^{18}$ R. Vieussens, loc. cit., ' . . . minor ac exterior . . . quae canthum minorem oculi respicit, plures emittit fibrillas, quae intra adipem nervum opticum ambientem, una cum fibrillis quibusdam e nervo tertii paris prodeuntibus, unum veluti plexulum, optici ipsius nervi truncum circumligantem, ejusque tunicis prospicientem efformant, et ejusmodi fibrillis emissis, adipem, qui posticam tunicae scleroticae partem obtegit, permeando, in fibrillas quoque desinit, quarum aliae binos oculi musculos deprimentem scilicet, et adducentem ingrediuntur, aliae vero tunicam scleroticam, circa posteriora penetrant, et in ipsa terminantur ... si quasdam excipias, quae ulterius pergendo, uveam subeunt, ex quo fit, ut in oculi convulsione, illius pupilla, anticam ac mediam modo dictae tunicae regionem occupans, supra modum dilatetur....

${ }^{10}$ Ibid., p. 171, “Crassior . . . propago . . . . in quatuor dirimitur surculos, quorum primus nervi optici trunco superato, e regione canthi majoris oculi, tunicam scleroticam subeundo, in membranam abit.'

${ }^{20}$ Ibid., ' . . . e foraminibus ossi cribriformi incisus transit, nasumque ingreditur, in quo . . . plures in fibrillas divisus per membranum interiora illius obducentem distribuitur.'

$\$ 1$ Ibid., "Tertius majorem versus oculi canthum pergendo ... partim in palpebras, et orbicularem earum musculum, et partim in exteriora nasi tegumenta, ac in musculos ipsum sursum moventes inseritur.’

22 Ibid., 'Tertius ramulus rami minoris superioris nervo sexti paris, et musculo abducenti subjectus, ad minorem usque oculi canthum porrectus, in glandulam innominatam, et unicam adnatam absumitur ....?
} 


\section{Pourfour du Petit's Experiments on the Origin of the Sympathetic Nerve}

Offsets of this nerve, described as supplying the masseter muscle [sic], some facial parts and the upper gums and teeth, were evidently alveolar nerves. ${ }^{23}$ It would seem, therefore, that the other branches of the maxillary nerve, which were referred to above, were probably nerves peripheral to the pterygopalatine ganglion, and may, perhaps, be identified as the pharyngeal branch and the palatine nerves. Thus, extensions are described by Vieussens as supplying the 'special white and spongy flesh below the bones of the palate' as well as the 'hard membrane and callous-like skin which covers the flesh'.24

Finally, the third and last division of the fifth nerve [mandibular nerve] was described by Vieussens and Willis as supplying [motor] nerves to the muscles of the side of the head, to the external ear, to the muscles of mastication, and to the muscles of the tongue, and as supplying [sensory] nerves to the tongue and to the teeth. ${ }^{25}$

The sixth cranial nerve, that is the abducent nerve, was described by Willis and Vieussens as arising from the lower part of the 'annular process', running anteriorly through the 'thick membrane' [dura mater], and entering the 'receptacle' at the side of the 'saddle', from which it was said to enter the orbit of the eye, where it ramified into many fibrils supplying the abducent muscles. ${ }^{26}$

So far we have not mentioned what for Willis and Vieussens was an important feature of the fifth and sixth cranial nerves, namely the recurrent twigs, which they believed were the roots of the sympathetic trunk. Willis explained that the nerve of the fifth cranial pair 'remits sometimes one, sometimes two twigs, which along with the other recurrent twig from the sixth nerve form the principal root of the intercostal nerve'. ${ }^{27}$ Describing the sixth cranial nerve, ${ }^{28}$ he wrote that near to the side of the Turkish saddle it 'sends back sometimes one, and sometimes a couple of twigs, which, joined with recurrent branches of the fifth nerve, form the principal trunk of the intercostal nerve'. And elsewhere, ${ }^{29}$ he described the principal trunk of the intercostal nerve as consisting of two or three twigs, "which were sent back from the fifth and sixth nerves, and joined together as in one stem'.

Vieussens described the ophthalmic branch of the fifth cranial nerve as 'emitting', sometimes one, sometimes two fibres, which with a fibre emitted from the sixth cranial nerve became attached to the intercostal nerve. ${ }^{30}$ Again, he described the sixth cranial nerve as emitting one fibre, which consisted of three fibrils, and to this

23 R. Vieussens, op. cit., pp. 171ff., T. Willis, op. cit., pp. 154ff.

24 $\mathbf{R}$. Vieussens, op. cit., p. $172, \ldots$ in plures quoque surculos dirempta per carnem peculiarem albam et spongiosam palati ossibus substratam, et per membranam duram, ac veluti callosam ejusmodi carnem obtegentem distribuitur.'

${ }^{25}$ Ibid., p. 172.

20 Ibid., p. 176, 'Nervi sextae conjugationis e tractibus albis, e media ovalis centri regione eductis, juxta infimam, cui annectuntur, processus annularis partem oriuntur; et ad anteriora tentendo, crassa meninge perforata, receptacula sellae equinae lateribus apposita subeunt . . . . Caeterum praedicti sextae conjugationis nervi, e supra memoratis receptaculis emergendo, oculorum orbitas ingrediuntur, ibique in plures fibrillas dividuntur, quae musculos abducentes penetrant, et in ipsis desinunt.'

${ }^{27} \mathrm{~T}$. Willis, op. cit., p. 153, ‘ . . et exinde surculum, modo unum, modo duos, remittit, qui cum surculo altero a nervo sexti paris refiexo, uniti nervi intercostalis radicem, sive caudicem constituunt.'

28 Ibid., p. 156.

20 Ibid., p. 184. 'Nervi intercostalis principium sunt bini vel tres surculi a nervis quinti et sexti paris reflexi, at in eundem truncum uniti .....

${ }^{30} \mathbf{R}$. Vieussens, op. cit., p. 170, … . modo unam, modo duas emittit fibras, quae una cum fibra e nervo sexti paris ibidem emissa, in nervum intercostalem desinunt.' 


\section{A. E. Best}

one or two fibres from the fifth nerve became attached in order to form the chief root of the intercostal nerve. ${ }^{31}$ Writing more specifically of the intercostal nerve Vieussens wrote: 'The two nerves commonly called intercostal, because they lie along the roots of the ribs within the pectoral cavity, trace back their recognised source to the fifth and sixth pair of nerves. For one twig from the sixth pair of nerves and two twigs from the greater branch of the anterior division of the fifth pair unite close to the side of the [Turkish] saddle to become attached to the trunk of the intercostal nerve, which turns back from its source, becomes affixed to the carotid artery, and leaves the skull'. ${ }^{32}$

Thus, as we see, both Willis and Vieussens were unequivocal in identifying the fifth and sixth cranial nerves as the source of sympathetic innervation. No other nerves, cranial or otherwise, were mentioned by these two anatomists as having this special relationship with the intercostal nerve. It has been claimed that this view was derived from Eustachius's diagrams, ${ }^{33}$ but this is not the case as far as the fifth cranial nerve is concerned. The assignment of such a role to the fifth nerve was almost certainly due to Willis, or to one of his collaborators.

Only those nerve fibres which extended from the sixth cranial nerve to the intercostal nerve were represented in the engravings of B. Eustachius. ${ }^{34}$ The relationship with the fifth cranial nerve, however, was described-although with considerable caution-by Giovanni Maria Lancisi, the Italian physician, who wrote the accompanying schedules for Eustachius' postumously-published work. 'There are those', he wrote in obvious reference to Willis, "who believe that the twigs from this [fifth cranial] nerve, along with those from the next [sixth], are supplied to energize the intercostal nerve and the splanchnic nerve'.35 And after explaining that the sixth cranial nerve, 'by far the smallest', takes its origin as filaments from the lower part of the 'annular prominence' [pons] and is borne laterally to the muscle of the eye which is commonly called the indignator [lateral rectus muscles], he goes on to say that 'it supplies a branchlet, however, to the upper division of the fifth pair, where it is distributed into the intercostals and (hence?) the viscera'. 'It is thus', he continued, 'that the distinguished Willis accounts for many passive responses'. ${ }^{36}$

Giovanni Battista Morgagni, who wrote important anatomical texts in the early decades of the eighteenth century, would not definitely commit himself to saying

\footnotetext{
${ }^{81}$ Ibid., p. 176, ' . . . e eque [i.e. in the receptacle alongside the 'saddle'] permeando, surculum unum, tribus interdum fibrillis constantem emittunt, cui modo una, modo duae fibrae, ex utroque ramo anteriore nervorum quintae conjugationis prodeuntes coalescunt ...:

${ }^{82}$ Ibid., p. 188, 'Nervi duo intercostales vulgo dicti, quod intra pectoris cavitatem, costarum radicibus accumbant .... Isti nervi parium quinti et sexti nervis originem acceptam referunt; etenim unus nervorum sextae conjugationis, et bini, rami majoris anterioris nervorum quinti paris surculi juxta utrumque sellae equinae latus simul coalescentes, in truncum nervi intercostalis desinunt, qui utrinque circa originem ad posteriora reflexus, arteriae carotidi subjicitur et . ...e calvaria emergit.'

${ }^{23}$ A. T. Rasmussen, Some Trends in Neuroanatomy, Dubuque, U.S.A., 1947, p. 7. Rasmussen claims that the erroneous view concerning the origin of the 'intercostal' nerve was due to the sixteenthcentury anatomist, B. Eustachius, whose diagram represents the sympathetic nerve as branching from the sixth cranial nerve.

3. Eustachius, Tabulae anatomicae (illustrated with preface and notes by G. M. Lancisi), Rome, 1714.

${ }^{2}$ Ibid., p. 45, 'Sunt qui hujus nervi surculos . . . ad informandum nervum intercostalem, et splanchnicum una cum sequenti dispensari arbitrentur.'

${ }^{36}$ Ibid., $\therefore$... ramusculum tamen largitur superiori quinto pari, ubi in intercostales et splanchnicos digeritur: unde clarissimus Willisius plura pathematum phaenomena explicat.'
} 


\section{Pourfour du Petit's Experiments on the Origin of the Sympathetic Nerve}

that there was any connection between the fifth cranial nerve and the intercostal nerve. ${ }^{37} \mathrm{He}$ wrote, "Certainly I have seen fibres, often many, sometimes only one big [fibre], falling away from the inner side of the sixth cranial nerve as it crosses the receptacle [cavernous sinus], and on one occasion [I saw] a fascicle which was more like a small ribbon than a fibre'. But he added, 'I do not readily recall having clearly seen accompanying fibres from the fifth cranial nerve, which were attached to these'. ${ }^{38}$

In spite of these reservations, however, some of the great anatomical texts, which appeared towards the end of the seventeenth century and during the early years of the eighteenth century, confirmed Willis's description of the source of the intercostal nerve. Thus Henry Ridley, in his small volume on the brain, described how, from the 'foremost branch'-that is, of the fifth cranial nerve-'two little ones turn back, and meeting with another small branch a little lower turned back also from the sixth pair, where that nerve is fastened to the outmost or borrowed coat of the carotid artery, make up a small trunk of a reddish or fleshy colour . . . which descending obliquely, and creeping under that artery, betwixt its external, proper, and borrowed coat, goes out with the carotid artery at the fourth hole of the skull'. He continues, 'and from its passage through the thorax, near the roots of the ribs (all along which, it receives a branch from the intercostal nerves) is called, the Intercostal Pair' ${ }^{39}$

William Cowper, who collaborated with Ridley in dissecting human bodies, and whose great anatomical treatise was published at the instigation of the Royal Society, wrote as part of the schedule for one of the superbly engraved tables: 'The intercostal nerve [is] composed of two branches from the fifth nerve ... joining with the body of the sixth in this subject [but], whether the disposition is constant, I must confess my late enquiries have not afforded me an opportunity of observing' ${ }^{40}$ There were other supporting claims. Thus, Bianchi, in a short anatomical treatise addressed to the Italian physician Nigrisoli, which is included in the collection of Manget, also described the intercostal nerve as originating in the cavernous sinus out of the fifth and sixth pair of cranial nerves. ${ }^{41}$

What is rather remarkable in these anatomical descriptions is that none of these people seems to have conceived the idea of demonstrating or refuting a connection between the fifth cranial nerve and the sympathetic trunk-for such, of course, was their intercostal nerve-by dividing the latter at some convenient point and observing the facial changes. Of course, they could not experiment on living humans, in which facial changes of colour are easily observed, but they were aware of the part played by the fifth cranial nerve in certain ocular responses, and any dependence, which there might have been between this kind of response and their so-called intercostal

${ }^{87}$ G. B. Morgagni, Adversaria anatomica omnia, Padua, 1719, Vol. 2, Book 6, p. 30.

${ }^{38}$ Ibid., 'Fibras autem quae ex quinto pari his socias se adderent, non facile memini satis luculenter vidisse ....'

${ }^{89}$ H. Ridley, The Anatomy of the Brain, London, 1695, p. 147f. Writing of the sixth cranial nerve (loc. cit), Ridley gave this description, 'It sends out sometimes one . . . . sometimes two slips .... for making up the trunk of the intercostal nerve, and after that (with the foremost branch of the fifth pair, in one and the same duplicature of the dura mater ... goes out at the second hole of the skull, and terminates in the abductory muscles of the eye.'

¿0 William Cowper, The Anatomy of Humane Bodies, Oxford, 1698, Appendix, 'The Sixth Table'.

1 J. B. Bianchi, Demonstratio anatomica, Turin, 1715. See J. J. Manget, Theatrum anatomicum, Geneva, 1717, p. 345, 'Par intercostale ex quinti, et sexti paris coalitu efformatum, oritur in cavitatibus hujusmodi sacci .... 


\section{A. E. Best}

nerve, could easily have been demonstrated by severing the trunk of this nerve in the neck of an animal. That they did not do this is especially remarkable, because it had been known from antiquity that the functions of certain nerves, especially those known as the 'tonic' nerves, could be studied from the induced effects of severing their trunks. Such procedures, with respect, for instance, to the ligation of nerve fibres controlling the voice or respiration, would be known to any student of Galen. Galen described in some detail how, to the surprise of onlookers, an animal would become suddenly dumb, if nerves 'near the carotid arteries' were bound with thread. ${ }^{42}$ 'It seems a remarkable thing', he wrote, that by the ligation of minute nerves in the back, the voice should fail. ${ }^{23}$ A large portion of Willis's account of the cranial nerves dealt with the vagus, his so-called 'eighth pair' of cranial nerves. Here he discussed whether heart-beats were dependent upon animal spirits which were supplied by the branches of this nerve, and whether if these resources were blocked the heart would stop beating. Hence, he described an experiment, which, he said, he had often carried out to answer this question. He described how, by laying open the vagus through incisions at the side of the jugular vein, and by constricting the exposed nerve with a tight ligature, he was able to produce the confirming syndromes in the animal. The dog, he wrote, seemed to stiffen at once, to lose its voice and to show convulsive chest movements and tremours of the heart, and although these abated, the animal lost all its verve and lay as though dying. ${ }^{44}$

Similar experiments were described by Richard Lower. He wrote that the movement of the heart is affected, if the supply of animal spirits is curtailed even for the shortest time. Thus, if the nerves of the 'eighth pair' are ligated or completely severed in the neck, the change is remarkable and sudden:45 for the heart, which until now may be beating moderately and evenly, begins to palpitate and waver, and the animal only survives for a day or two, palpitating and without energy. He explained, in passing, that the animal does not die at once, only because of supplies made available by the recurrent nerve from the vagus and by intercostal branchlets, which come from the 'plexus below the entrance to the chest', and which are received by the vagus trunk, before the latter sends twigs to the heart.

The apparent relationship between certain cranial nerves and the nerve which had been described by Willis as the intercostal was rationalized by prevailing theories of the function of the latter in providing a certain reciprocity in the responses of different parts of the body.

Willis compared the intercostal nerve to a bush growing upon another, so that although there is only one source of animal spirits, namely the cerebellum, the com-

18 C. Galeni opera omnia, ed. Kühn, Leipzig, 1821, Vol. 2, pp. 667ff.

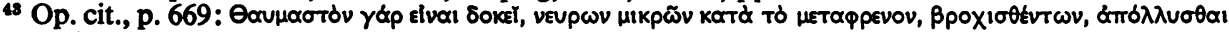
Thu pwutiv.

$4 \mathrm{~T}$. Willis, Cerebri anatome cui accessit nervorum descriptio et usus, London, 1664, p. 171f, 'Atque hic jure inquiritur, utrum cordis pulsus a spirituum animalium per nervos influxu ita necessario dependeat, ut eo prohibito cordis actio omnino cesset? Pro hujus decisione experimentum sequens in cane vivo aliquoties tentari curavimus: circa jugulum, cute per longum discissa, utrique paris vagi trunco seorsum arrepto ligatura valde stricta injiciebatur; quo facto, statim canis torpescere visus obmutuit, et circa hypochondria motus convulsivos cum magno cordis tremore passus est: verum hoc affectu brevi cessante, postea sine vigore quovis aut vivido aspectu, quasi moribundus jacuit, ad motum quemvis piger aut impotens ...

${ }^{45}$ R. Lower, Tractatus de corde, Amsterdam, 1671, p. 81, ‘. . mirum dictu quanta subito mutatio!, 


\section{Pourfour du Petit's Experiments on the Origin of the Sympathetic Nerve}

munication between the two nerve-systems allows them to be distributed throughout the ramifications of each, and it was thus, according to Willis, that the rapid concomitance between actions and involuntary passions was maintained in different parts of the animal's body. ${ }^{46}$ The fact that the intercostal nerve appeared to rise from the roots of the fifth and sixth pairs of cranial nerves, and did not originate directly in the cerebellum itself, was sufficient for Willis to explain why, so promptly without the intervention of the brain, and as if through one and the same act, the eyes and especially parts of the face and the mouth would respond to the movements of the midriff and viscera which were under the control of the intercostal nerve. ${ }^{47}$

Instances given by Willis and Vieussens of such concomitant responses were of sneezing and of those obtained by tickling a person's ribs. ${ }^{48}$ 'As soon as the nerve fibres which lie over the nostrils are wrinkled by irritation, the diaphragm, on account of the rather different [rate of] breathing is immediately pressed down by the flow of animal spirits in the intercostal nerve. Then by a spasmodic slackening of the nostrils the septum is forcibly drawn back producing a stronger expiration and a forceful emission of air'. He went on to say, 'similarly [but], in a contrary direction, when the diaphragm contracts through the tickling of the ribs, it causes laughter, the face and mouth being contorted involuntarily.' Vieussens wrote: 'On account of the source of those [intercostal] nerves-which is borrowed, as it wereand on account of the frequent communication, which they have with the nerves of the eighth pair [the vagus nerves], it comes about that there is so much concord between the brain and the viscera, and that for the various dispositions of the brain, and indeed for the various ideas aroused in the mind by the operation of the brain, the viscera are affected in various ways. Hence it can be demonstrated why the eyes, lips and other facial parts, which are supplied with nerve fibres of the fifth and sixth cranial pairs exhibit various changes according to the different motions of the midriff, even when one is unaware or, indeed, unwilling.' 49

Willis and Vieussens were obviously anxious to make the point that the flow of animal spirits within the intercostal nerve, could occur either downwards or upwards,

46 T. Willis, op. cit., p. 184f, ‘. . succrescit enim ut frutex super alio frutice, ideoque ramificatione duplici, scilicet tum propria, tum ista parentis sui, communes utriusque virtutes ac influentias dispensat: qua ratione efficitur, ut inter conceptus cerebri et praecordiorum affectus, necnon inter actiones passionesque fere omnium totius corporis partium, quae ad functionem involuntariam pertinent, consensus et commercia quam citissima habeantur'.

${ }^{47}$ Loc. cit., 'Quatenus autem idem intercostalis nervus in illorum caudicibus, et non immediate in cerebello radicatur; haec ratio est, cur oculi, necnon oris et faciei partes, quibus par quintum et sextum prospiciunt, adeo prompte et cerebello inconsulto, eodem velut actu, praecordiorum et viscerum motibus, quos nervus intercostalis efficit, correspondeant; et vice versa, illarum actioni horum motus e vestigio obsequantur.'

${ }^{8}$ Loc. cit., ‘. . . in sternutatione, quamprimum fibrae nervosae nares oblinentes [sic] a vellicatione corrugantur, illico nervi intercostalis commeatu, diaphragma propter inspirationem altiorem aliquandiu deprimitur; dein narium spasmo remittente, etiam septum violenter retractum Extvonv fortiorem cum vehementi aeris exsufflatione praestat: Pariter e contra, cum titillatione super costas facta diaphragma spasmo affectum cachinnos movet, una facies et ora in risum pathetice configurantur.'

${ }^{4} \mathrm{R}$. Vieussens, Neurographia universalis, Leyden, 1685, p. 189, 'Propter nervorum istorum natales velut mutuatitios, et crebram communicationem, quam cum nervis octavi paris habent, efficitur ut inter cerebrum et viscera . . . tantus habeatur consensus, ut pro variis cerebri affectibus, imo et variis animae ideis cerebri ipsius ministerio excitatis, varie praedicta viscera afficiantur: et vice versa pro variis praedictorum viscerum dispositionibus, cerebrum necnon anima ipsa varie afficiantur ... Inde quoque ratio deduci potest, cur oculi, labra et reliquae faciei partes, quibus nervorum paria quintum et sextum propagines impertiunt, promptissime ipsaque anima nesciente, uno et reluctante, diversis praecordiorum motibus obsequentes diversas mutationes patiantur . .. 


\section{A. E. Best}

depending on the circumstances. The fifth cranial nerve was seen as a system which was admirably adapted not only to bring about overt responses to certain thoughts, but to relay innervation to the lower parts of the body, including the genitals. In describing, for instance, the maxillary division of the fifth cranial nerve; Willis explained how its finer extensions climbed up and entwined around the blood vessels which supply the face. It was thus that one's 'indecorous' thoughts led to an influx of animal spirits into this branch, which caused the constriction of the veins and the retention of blood in the face. ${ }^{50}$ But the same animal spirits that produced this response, might, through one's view of something, be deflected from the ophthalmic division of the fifth nerve into the intercostal nerve, where they would bring about a different response in another part of the body. ${ }^{51}$ Furthermore, the flow of animal spirits could take place in the reverse direction, and from some change in the lower parts of the body could produce concomitant changes in the face. As we have adumbrated above, the important contribution of Pourfour du Petit was that, as far as the extensions of the intercostal nerve into the head are concerned, the flow of energy is in one direction only, namely upwards.

Pourfour du Petit published his paper which refuted the view concerning the origin of the intercostal nerve in the Mémoires de l'Académie Royale des Sciences for $1727 .^{52}$ After mentioning the circumstances which led him to write this paper, he described how, as early as 1705, after a scrutiny of Vieussens' 'twenty second plate', he was already doubting whether the intercostal nerve was of cranial origin. He was then physician to the Hôpitaux du Roi at Namur, and having access to bodies was able to discover 'many facts about the brain and nervous system'. Whilst dissecting the intercostals he found that the arrangement of these nerves in joining on to the fifth and sixth cranial pair was from the posterior to the anterior end as shown in Figure 3 of his diagram. ${ }^{53}$ Other dissections had confirmed this.

He described the intercostal nerve (A,A) as entering the skull along with the carotid artery by passing under the membrane which enveloped the artery in the 'twisted, petrous tube'. This nerve [carotid nerve] was seen to project several fibres $(\mathrm{i}, \mathrm{i}, \mathrm{i})$, around the artery, thus arriving in the hollow of the 'sphenoid saddle'. Having severed the carotid artery, he wrote, he was able to see the 'plexus' (FF)-the small remarkable net described by Willis and other anatomists, which was formed through the 'divisions and reunions' of the nerve in this 'receptacle'. ${ }^{54}$ This 'plexus', he observed, which was 'very fine in the dog and in the wolf', supplied branches of varying

${ }^{50}$ T. Willis, op. cit., p. $155, ` \ldots$ proinde ut ejusdem nervi propagines vasa sanguifera amplectentes, eadem comprimendo convellendoque, sanguinem in genas et faciem plus satis urgeri, ibidemque venis constrictis, aliquandiu sisti ac detineri faciant.'

$s 1$ Ibid.

s2 Pourfour du Petit, 'Mémoire dans lequel il est démontré que les nerfs intercostaux fournissent des rameaux qui portent des esprits dans les yeux', Mém. Acad. r. Sci., 1727, p. 3.

53 See fig. 2, Photographic Reproduction of du Petit's Diagram, fig. 3.

64 Pourfour du Petit, op. cit., p. 3f, 'j'ai coupé l'artère Carotide en cet endoit pour laisser voir le plexus FF que ce nerf forme par ces divisions et réunions dans ce réceptacle . . . . On trouve souvent dans ce plexus plusieurs Ganglions très petits. Willis, et d'autres Anatomistes ont pris ce plexus pour un petit ret admirable, il est tres beau dans le Chien et dans le Loup. Il fournit des rameaux plus ou moins déliés à la dure-mère, à la glande pituitaire, à l'artère Carotide avec laquelle ces rameaux se distribuent: mais les plus considérables EE se joignent au cordon antérieur de la $5^{e}$ paire CK. Ils sont pour l'ordinaire deux, comme on le voit dans cette figure. Il y en a un troisième D qui se joint à la $6^{\circ}$ paire GH.... 

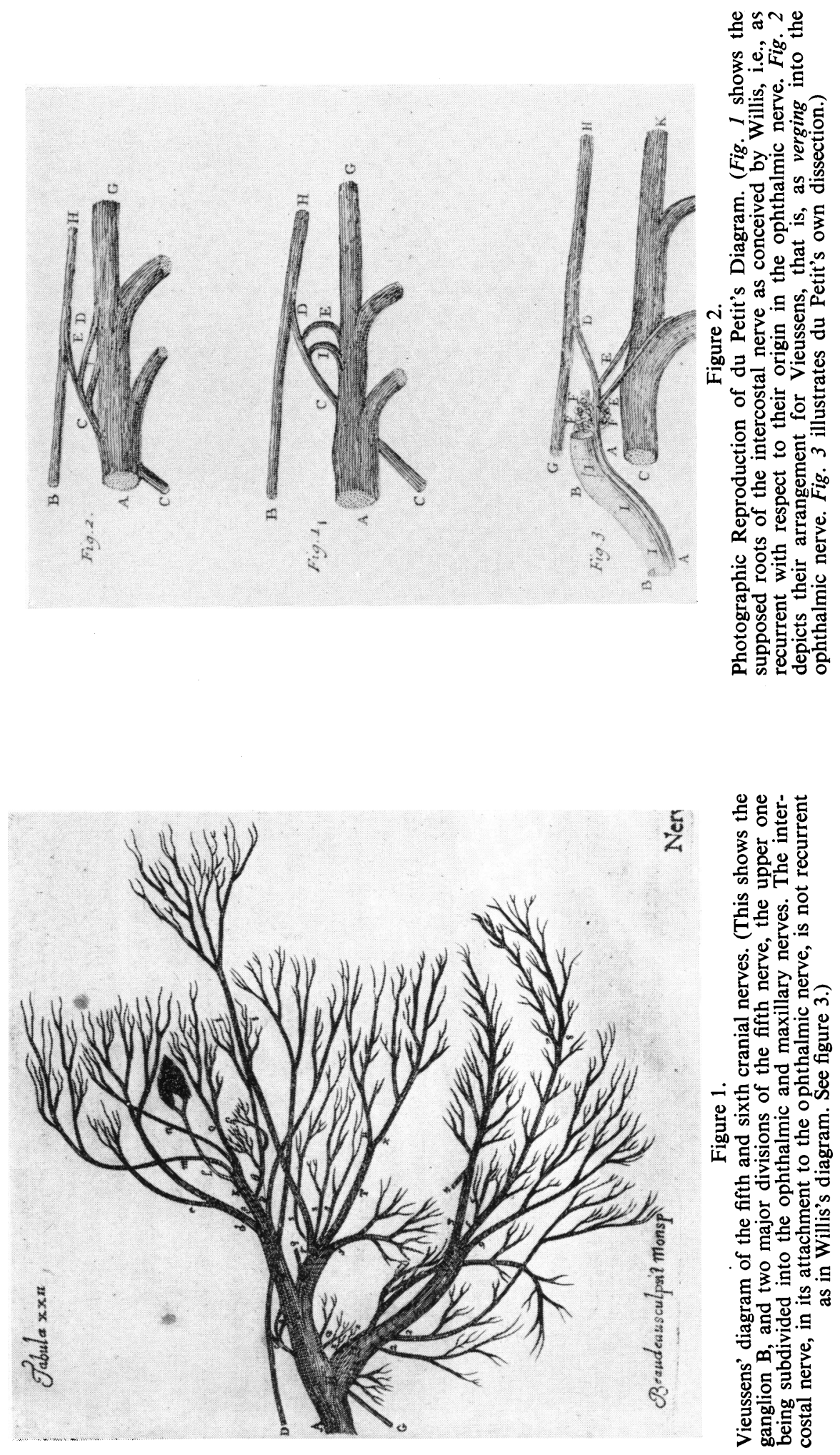

눈 包它范 के 氞远

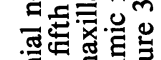

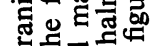
๖.

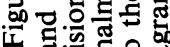

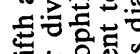
눙요

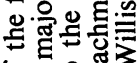

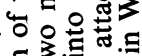

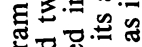

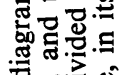
in

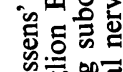

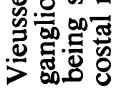




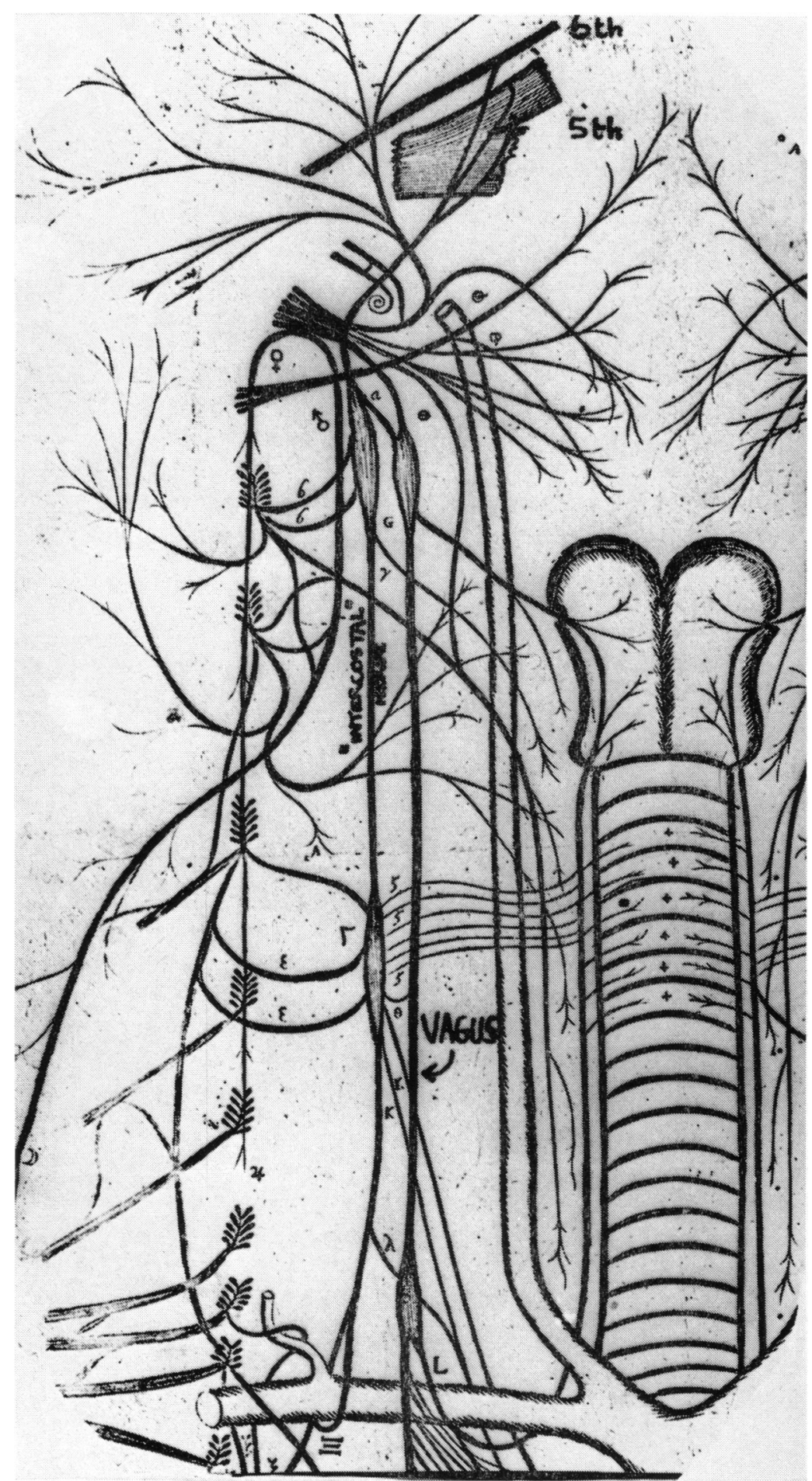

Figure 3.

Photographic reproduction of part of Willis's diagram showing the relation between the cranial and intercostal nerves. (The supposed roots of the intercostal nerve as shown in this engraving, which was undertaken for Willis by Christopher Wren, bend round from their place of emergence from the fifth cranial nerve.) 


\section{Pourfour du Petit's Experiments on the Origin of the Sympathetic Nerve}

slenderness to the dura mater, to the pituitary gland and to the outer coat of the carotid artery; larger ones, however, of which there were usually two, as in the figure, joined on to the anterior cord of the fifth pair, and a third one joined on to the sixth pair.

His point, made rather more clearly in the abstract of his paper than in the paper itself, was that since these slender twigs joined on to the fifth and sixth pair in the opposite direction from that shown in the diagrams of Willis, this excluded the possibility of 'animal spirits' flowing from the source of these cranial nerves into the intercostal extensions. 'For if the intercostal did stem from them, the question would naturally arise as to how it received animal spirits-how the fifth and sixth nerves supplied the intercostal with fluid, in view of the direction of flow within them (dans leur cavite); that is to say, stemming from the fifth and sixth nerves, the intercostal would have to originate from the same direction as their origin'. The author of this abstract went on to say, 'M. Petit has shown that the intercostal was, with respect to the [superficial] origin of these nerves, attached in the opposite direction, so that fluid could not pass into the hollow of this nerve except by turning, impossibly, round'. ${ }^{55} \mathrm{Du}$ Petit supported his argument also by the relative thickness of the nerves. First, careful inspection of the intercostal nerve showed that, instead of becoming thicker as it approached its supposed source, it actually became attenuated, the twigs being thinnest where they merged into the fifth and sixth cranial nerves. Second, the trunk of the sixth nerve was thicker after receiving the extension of the intercostal nerve, though, because of its size and adherence to the dura mater, the ophthalmic branch of the fifth nerve did not show such obvious thickening. ${ }^{56}$

Du Petit explained that it was not possible to trace the course of the intercostal nerve fibres beyond their points of attachment to the fifth and sixth pair. He claimed that, in the case of the wolf, ramifications of the intercostal nerve could be traced as twigs of the ophthalmic nerve, but otherwise one could only speculate on what happened. ${ }^{57}$ Whereas he was sufficiently satisfied that the intercostals did not arise from these cranial nerves, he conceded that this was not enough to convince other anatomists. Accordingly he tested his hypothesis by certain experiments. 'I conceived the idea', he wrote, 'that if I severed the intercostal of a live dog, it should bring about certain changes in the eyes. From this it would follow that it is the intercostal nerve which supplies the animal spirits [to the eyes]'.

An inspection of Willis's diagram, which shows the downward course of the intercostal nerve, ${ }^{58}$ would suggest that the most obvious place to cut the intercostal nerve for the purpose of this experiment is in the neck of the animal. Du Petit was aware that in dogs and in other quadrupeds the intercostal is enveloped in the same sheath as that of the eighth pair, and that one cannot be divided without the other'. He made the point, however, that the eighth pair supplied no branches to the eyes, ${ }^{50}$ and that

ss 'Sur ce que le nerf intercostal fournit des esprits aux yeux', Hist. Acad. r. des Sci., 1727, p. 7.

so Pourfour du Petit Mém. Acad. r. Sci., 1727, p. 4.

s7 Pourfour du Petit, Ibid., ‘. . . ainsi tout ce que je viens d'avancer peut tout au plus passer pour une simple probabilité.'

${ }_{58}$ See fig. 3, Photographic Reproduction of Part of Willis's Diagram showing the Relation between the Cranial and Intercostal Nerves.

so Ibid., p. 4f., ‘. . nous sommes bien sûrs que la $8 \bullet$ paire ne fournit aucun nerf aux yeux, cela peut produire aucun équivoque dans l'expérience.' 


\section{A. E. Best}

by cutting it along with the intercostal trunk one would not affect the kind of results, which he expected to obtain. One could, he explained, use a monkey, in which the intercostal nerve is not encased in the same membrane as the vagus, and in which it is possible to separate the two nerves quite easily.

His experiments fall into two series. The first series belongs to the early part of 1712 at Namur; the second series to the latter part of 1725 in Paris. It would be rash to ascribe too much to his reflections of 1705 . If at this time he did suspect the accuracy of Willis's remarks which concerned the source of the intercostal nerve, it is most unlikely that he was giving any serious thought to the part played by the intercostal nerve in ocular responses. We say it is unlikely because of letters published at Namur in 1710, in which he described some observations on patients in the military hospital, which were made, presumably, about the time of, or shortly after, the fighting of 1709.60

These observations of du Petit were partly in confirmation of sections of Theophilus Bonet's Sepulchretum sive anatomia practica (1679), though they were mostly restricted to the after-effects ('contre-coups') of certain brain injuries of soldiers who had been brought into the hospital. A medley of wounds are described, which include piercings and abrasions from swords and sticks, concussions from falling objects, and damage from deeply penetrating bullets. He was chiefly interested in various paralytic effects. His conclusions were that limbs and other moving parts of the body are set in motion by animal spirits supplied from that side of the brain which is opposite to that of the parts moved, that the spirits which set the limbs in motion came from the hemispheres of the brain, and that 'contralateral' paralysis was complete only when the 'corpus striatum' on either side had been affected.

His techniques were precise and systematic. These entailed: (1) a careful observation of all the symptoms as long as the patient survived; (2) an immediate dissection and examination of the patient's brain after death; (3) the simulation, as far as practicable, of the same injuries in a dog, and the observations of the symptoms; and (4) the immediate post-mortem dissection of the brain of the dog. Yet, apart from one brief reference to the dulled appearance of an eye and the ptosis of an upper lid as part of the paralysis on one side of a soldier who had had a 'light pleurisy' (sic), he made no allusions to the appearance of the eyes, when he was recounting the different 'contre-coups'. He referred to the intercostal nerve in one of these letters, and described the effects of pinching its various branchings. In fact, he even described the result of pinching the associated intercostal and vagus nerves 'opposite to the carotid artery' saying that it produced 'no contraction either of the heart or of the lower stomach', but he made no reference at all to what might have been observed in the eyes. ${ }^{61}$

The simple explanation is that before 1710 he was not interested in the effects in the eyes, and he betrays this by a remark in his 1727 paper which was published in the Mémoires de l'Académie. Referring briefly to the effects on the heart, breathing and voice through the severance of the associated intercostal and vagus nerves, he

'o Lettres d'un Médecin des Hópitaux du Roy, 1710, p. 6.

-1 Ibid., p. 21, … . vous verrez différentes parties se mettre en contraction selon les différentes fibres du nerf qui feront comprimés . . . j'ay pincé l'intercostal et la huitième paire vis-à-vis les carotides, mais ne s'est fait aucune contraction, ni au coeur, ni aux parties du bas-ventre.' 


\section{Pourfour du Petit's Experiments on the Origin of the Sympathetic Nerve}

said that Willis and others had not observed the effects in the eyes because 'Their attention was not directed there. The experiments which they performed were only concerned with the eighth pair, whilst I have been concerned with the intercostal pair'. ${ }^{62}$ If, however, du Petit had been asking himself crucial questions about the source of the intercostal nerve as early as 1705 , it is hardly likely that he would have raised the subject in this way in $\mathbf{1 7 1 0}$ with no hint of its relevance. We suggest that his real interest in the sympathetic nerve was aroused by subsequent observations which he made whilst repeating the performance of constricting the cervical extension of this nerve. It is plausible to suppose that his attention was directed by chance to the observable changes in the eyes of the animal, when he was again investigating the effect of pinching the cervical branch of the intercostal nerve, and that this led to close scrutiny of the fifth and sixth cranial nerves and of the so-called intercostal nerve in the light of what Willis and Vieussens had written. This would supply a likely background to the series of experiments, carried out in 1712, which was eventually published in Mémoires de l'Académie Royale des Sciences. The experiments described in this first series were as follows: ${ }^{\text {Bs }}$

Experiment 1, February 1st

I cut the cord of the intercostal and of the eighth pair on the two sides of a live dog, opposite to the third and fourth vertebrae of the neck. It first lost its voice, and after an hour the eyes were seen to have become dull. It breathed heavily with the whistling noise of an asthmatic, and it died seven hours later.

Experiment 2, February 12th

I cut the cord of the intercostal and of the eighth pair on the two sides of a live dog. First it lost its voice and after some hours its eyes became dull. It had no difficulty in breathing, but it was very restless, and there was a quivering movement of the heart. It continually vomited what it had had to drink and eat, and its eyes became mattery and smaller than they [usually] were. It died on February 19th.

[Although there was no doubt about the changes which had occurred in the eyes of the dog, du Petit was aware that this might have been due to shock and pain. Accordingly, he decided to carry out the division of the nerve on one side of the neck only].

Experiment 3, February 23rd

I cut the cord of the intercostal and of the eighth pair on the right side only. First the dog lost its voice, and after half an hour I noticed that the right eye had lost much of its lustre. It showed those syndromes (accidens) described in Experiment 1, which led me to suppose that it would die in the same way afterwards. However, the syndromes became less marked, though they showed up again rather strongly after it had drunk and eaten, or when it was angered by another dog which came into the kitchen. There was still a tendency to nausea; sometimes it would reject its food with considerable effort, and would then begin to eat again gnawing its bones eagerly. Its right eye began to be filmy and, three days after the operation, it was discharging a great deal of matter. By the beginning of March, the wound was found to be healed. It died on the 15th of the same month after an extraordinary bout of eating.

I dissected the two eyes of the dog. There was a little inflammation of the right eye, but nothing else was amiss except that the volume of the humours was less and the eye was smaller.

Experiment 4, March 20th

I cut the cord of the intercostal and of the eighth pair on the left side of a dog. Its voice did not fail-it was only sharper and more feeble. The left eye was found to be less alert and the nictitating membrane (la membrane particulière) in the major canthus (du grand coin) of the eye had advanced over the cornea. The eye shed tears for some time. Although the dog was

62 Pourfour du Petit, op. cit., Mém. Acad. r. Sci., 1727, p. 7.

as Ibid., 5-7. To avoid repetition, we have made some slight abridgements in the translation of du Petit's text. 


\section{A. E. Best}

inclined to nausea when eating, its breathing was sound. In due course it recovered and became quite sportive, its left eye having again regained almost all its lustre. ${ }^{44}$

Experiment 5, April 9th

I carried out the same experiment on the same side of another dog, and this was equally successful..$^{\circ 5}$

\section{Experiment 6, April 10th}

I carried out this experiment on the right side of another dog. It did not lose its voice as the one did in Experiment 3, and it showed no tendency to vomit and no [signs of] difficulty in breathing. The nictitating membrane in the major canthus of the eye had encroached over the cornea, [but] the eye appeared to be only slightly bleared (terne) and watery (larmoyant). After two months the same eye had gradually recovered all its lustre, [though] it was not quite as alert as the eye on the left side.

\section{Experiment 7, April 17th}

Using another dog, I cut the same cord of the intercostal and of the eighth pair, first on the right side. The dog lost its voice. After a quarter of an hour I operated on the left side. The dog showed no desire for drink or food, but it did not vomit at all. Its eyes lost their lustre and became so mattery and so sunken, that it scarcely appeared different when it died on April 21st."6

In each case the affected eye had become dull, sunken, moist and mattery, and in each case the nictitating membrane had encroached over the cornea. ${ }^{67}$ All this, du Petit concluded, showed 'the absence of animal spirits which are supplied by the intercostal nerve'. His paper of 1727 , which describes also the second series of experiments, contains results which were not apparent to him in 1712, at the time of his first series of experiments which we have just given here. Nevertheless, some of the general conclusions of his 1727 paper, though confirmed by what he observed in the second series of experiments, clearly belong to the 1712 period of his speculations. Though published so long after, he had already reached important conclusions in 1712, and one of these was that the 'fibres' which held back the cartilaginous membrane [nictitating membrane], were innervated by the intercostal nerve, for the severance of this nerve, provided other conditions remained the same, led to the release of the membrane. It was the failure of this nerve on the death of such an animal as a dog or a cat that brought about the extensive encroachment of the nictitating membrane across the cornea-in the case of the dog across the entire surface of the cornea. ${ }^{68}$

As one can see there is no mention of the pupils of the eyes in the 1712 series of experiments. Prima facie, this is surprising, for he must have examined the eyes very closely. On reading his second series of observations, however, it is evident that what happened to the pupils was not a readily observable syndrome. He used no superlatives to describe the degree of contraction, and where he employed measurement to compare the diameters of pupils of the affected and non-affected sides, the result though positive, was hardly impressive. What would seem to be the case is that his observations of the pupils were undertaken to confirm certain theoretical speculations, his own and, probably, those of others, concerning the function of the ciliary nerves.

By the early 1720 s du Petit was convinced that the sympathetic nerve had its

"' 'Son oeil gauche avoit repris tout son brillant à peu de chose près.'

6 '... . et qui a réussi de la même manière.'

6... qu'il n'en voyoit presque plus lorsqu'il est mort .....

77 Ibid., p. 7.

os Ibid., p. 13. 


\section{Pourfour du Petit's Experiments on the Origin of the Sympathetic Nerve}

superficial origin at some place in the spinal cord, ${ }^{69}$ and that it was only as a tributary that its upper extension supplied fibres to the fifth and sixth cranial nerves, along with the ramifications of which it eventually supplied the eyes and, probably, the ears and face. It had already been claimed by Vieussens that the dilatation of the pupils was effected by ciliary extensions of the ophthalmic nerve, ${ }^{70}$ but even by the early 1700 s the description of these nerve fibres was still largely conjectural. $F$. Ruysch, who tried to examine the course of these fibres between the sclera and the choroid of the eye, believed that their sole function was to innervate the ciliary muscles. ${ }^{71}$

At some time during, or perhaps rather before, 1725 , whilst specializing in the removal of cataract, du Petit's attention was directed to these ciliary nerves between the membranes of the uvea, ${ }^{72}$ and he was left in no doubt that these fibres also controlled the pupillary appertures. That they contained extensions, albeit remote ones, of the intercostal nerve, was something that might be verified by a series of experiments similar to those carried out in Namur in 1712. This he promised to do.

He gave a fuller account of these anatomical speculations, which were to form the background of his second series of experiments, in his paper of $1727 .^{73}$ Thus he described the trunk of the nasociliary nerve as emitting a 'branch', which, along with another branch from the third cranial nerve, formed, certainly in man, a small ganglion [ciliary ganglion]. From this ganglion, he said, slender fibres attached themselves to the outer membrane of the optic nerve, from which either in bundles or singly they went out to the back of the eyeball, where some, by running between the sclerotic and the choroid, extended as far as the cornea. Hence, the ciliary nerves, which, he claimed, ought more appropriately to have been called the 'pupillary nerves', whose associations with the intercostal nerve had not been perfectly recognized by Willis and Vieussens, and whose origin had eluded Ruysch, were supplied with 'animal spirits' by the third, fifth, and sixth cranial nerves, and by the intercostal nerve.

Without saying who they were, du Petit revealed that people were already canvassing the theory that the ciliary nerves received their supplies of animal spirits

'D 'Mémoire sur plusieurs Découvertes faites dans les Yeux de l'Homme . . . Mém. Acad. r. Sci., 1726, p. 69, 'L'on n'avoit pas compté jusqu'à présent le nerf intercostal entre les nerfs qui se distribuent dans les yeux: on a cra .... qu'il tiroit son origine de la cinquième et de la sixieme paire des nerfs du cerveau: mais j'ai découvert que ce nerf doit sa naissance aux nerfs vertébraux, et que quelques rameaux de la branche qui accompagne l'artère carotide interne vont se joindre à ces deux nerfs pour se distribuer dans les yeux, peut-être aussi dans l'oreille et dans le visage pour y exciter les mouvemens pathétique.'

${ }^{30}$ See note 18 above.

11 F. Ruysch, Thesaurus anatomicus, Amsterdam, 1701, vol. 2, p. 6. 'Per superficiem choroideae decurrunt sex septemve nervuli ciliares, et recto quidem tramite, suntque albicantes, et propterea facilis eorum discretio a vasis sanguiferis ..... (fit).

Dicti nervi per superficiem choroideae reptantes, nullum visibilem ramusculum videntur elargiri choroidea; cum autem ad ligamentum ciliare, ut et ejus processum perveniunt, ibi ramulos dispergere videmus; hinc nervi ciliares a me sunt denominati.'

12 Pourfour du Petit, 'Mémoire dans lequel on détermine l'endroit où il faut piquer l'oeil dans l'opération de la cataracte', Mém. Acad. r. Sci., 1726, p. 264. 'Mais à quelque distance de la cornée que l'on perce l'oeil, l'on peut recontrer et piquer, et même couper entierement un rameau des nerfs ciliaires . . . . je prouverai . ... dans un autre Mémoire que je donnerai exprès sur cette matière, qu'une branche de l'intercostal s'étant jointe à la carotide, la fuit dans le crane où elle fournit des rameaux à la $5^{\circ}$ et à la $6^{\circ}$ paire, qui vont en partie se distribuer dans les yeux, et forment les nerfs ciliaires."

73 Pourfour du Petit, 'Mémoire dans lequel il est démontré . . ', Mém. Acad. r. Sci., 1727, p. 11 . 


\title{
A. E. Best
}

wholly from the intercostal nerve, that the association of the fibres of the intercostal nerve with the ramifications of certain cranial nerves was, presumably, simply a matter of anatomical economy. ${ }^{74}$ Perhaps there is discernible in this a presage of other theories, besides that of animal spirits, which might explain the transmission of energy along nerve fibres. Already, anatomists, who had caught glimpses through their microscopes of the fascicular structure of slender nerves, were voicing their dissatisfaction with the theory of animal spirits. ${ }^{75} \mathrm{Du}$ Petit objected that it was implausible that such slender twigs which verged into the membranes of the ophthalmic nerve and the sixth cranial nerve could emerge as the so much greater 'volume' of fibre necessary to make, not only the ciliary nerves, but the other sympathetic extensions to the eyes, nose and face. ${ }^{76}$ At times, however, he would appear to be maintaining that the extensions of the intercostal nerve in the ciliary nerves were present as independent fibres, and it was thus that the intercostal leads right into the eyes'. ${ }^{77}$ Certainly, a part of the object of the second series of experiments, would appear to be to confirm that at least some of the nerve fibres that penetrated the back of the eye were of sympathetic origin. That he confused the issue towards the end of his paper by trying to give explanations of the syndromes in terms of the theory of animal spirits, can only be explained as loyalty to the mechanistic Cartesian doctrines, which still pervaded the French academic tradition.

The series of experiments carried out in 1725 and published in 1727, were intended primarily, therefore, to confirm the theory that the energy transmitted to the eyes by the intercostal system of nerves was through continuous, individually distinct fibres, which extended from the trunk of the body upwards into the head. We are told that the experiments were witnessed by Winslow, Sénac and Hunauld.

\begin{abstract}
Experiment 1, September $18 \mathrm{th}^{\mathbf{8}}$
I severed the cord of the intercostal nerve and of the eighth pair on the right side of a dog. It did not lose its voice and there was no immediate change in the right eye, but after a quarter of an hour the eye appeared to be less bright than the left one, and the nictitating membrane (membrane cartilagineuse), which these animals possess in the inner corner of the eye, had encroached a little over the cornea.
\end{abstract}

September 19th

It showed no tendency to vomit; there was no palpitation, but it breathed with difficulty. I observed four symptoms in the right eye, which were not present in the left. First, the nictitating membrane, which these animals possess in the inner corner of the eye, had encroached over the cornea, covering about a quarter of the disk. Second, there was some matter in the major canthus of the eye on the nictitating membrane. Third, the cornea was less convex. Fourth, the pupil was less dilated than that of the left eye, all these effects making the eye dull (morne) and shrunken.

September 21st and 22nd

The dog did not want to eat.

September $23 r d$

The dog ate and was quite lively. It had no difficulty in breathing. The condition of the eye,

74 Ibid., p. 12.

75 William Cowper, The Anatomy of Humane Bodies, Oxford, 1698, Introduction, 'The utmost I could yet observe in viewing the nervous fibrillae with a microscope ... is, that they are formed of a reticulated compages of fibres .... This structure of the nervous system seems to plead against those hypotheses of the animal functions, founded on the motions of the spirits or fluids derived from the brain, and transmitted by the nervous channels ...

${ }_{76}$ Pourfour du Petit, Mém. Acad. r. Sci., 1727, p. 12.

77 Ibid., p. 12.

${ }^{78}$ Ibid., pp. 8-10. 


\section{Pourfour du Petit's Experiments on the Origin of the Sympathetic Nerve}

however, remained the same, except that there was no longer any matter, and it remained thus until September 30th, when I noticed that the cornea had regained its convexity and the eye was bright, though the nictitating membrane remained in the same place (état) as before on the cornea; the pupil was larger. The dog had become fatter since the operation, and the wound had almost healed.

Experiment 2, October 5th

As the scar had now closed a little, I severed the cord of the intercostal and of the eighth pair on the left side. After a quarter of an hour, the nictitating membrane had encroached over the cornea. The dog, which had gone to eat before I operated on it, vomitted. Its left eye had become dull and mattery, the cornea had become slightly flattened and the pupil had contracted. It no longer had any inclination to eat after this operation. It died on October 8th, that is, three days after the operation.

Du Petit then went on to describe his dissection and examination of the affected eyes. He wrote, 'The nictitating membrane extended over the diameter of the cornea of the left eye to a distance of a line and three quarters, whereas on the right eye it extended only a line and a half. The whole conjunctiva of the left eye was inflamed, though there was no inflammation in the right eye. The pupil of the left eye was two lines in diameter, whilst that of the right was two and a half lines. There was nothing exceptional in the other parts of the eyes.'

\section{Experiments 3, 4, and 5, October 18th}

I carried out experiments on three dogs. I cut the intercostal nerve of the first dog on the right side. I cut [the same nerve of] the second [dog] on the left side, and I cut the intercostal nerves on each side of the third dog.

Three or four minutes after the operation, the nictitating membrane had encroached over the cornea of the right eye of the first dog; it had encroached on the left eye of the second dog, and on the two eyes of the third dog, the encroachment on the right side being more extensive than that on the other side. After an hour the pupil was found to be smaller in the first two dogs in the eyes on the same side as the operation, but what was striking was what the two pupils were very dilated in the case of the third dog, the dilation being greater in the right eye than in the left. This [third] dog, which survived for only twelve hours, had great difficulty in breathing and there was palpitation of the heart.

The other two dogs had no difficulty in breathing and they did not vomit.

The cornea became slightly less convex on the side of the operation. The affected eyes were still very lustrous, but not quite as much as those on the opposite side. The dog, on which the operation had been performed on the right side, lost its voice, but the other dog was barking quite well.

October 20th

The nictitating membranes [on the operated sides] of these two dogs were [now] not as extended so far over the cornea, and the pupil was smaller on the side of the operation. There was no matter, [though] the colours of the iris were less lustrous.

The wounds of the first two dogs had [now] healed, but in the case of the dog in which the intercostal had been cut on the right side, the pupil of the eye on the side of the operation remained permanently smaller. ${ }^{70}$ The eyes, which had been slightly dull, had [now] regained their lustre, and I observed that the cornea had become gradually more convex. Again, I carried out other operations on the right side and on the left, and the same phenomena followed, which shows that the eye receives spirits through the intercostal nerve.

The value of this research is in du Petit's discovery that the dilator muscle of the pupil is partly innervated by fibres in the cervical sympathetic chain. We say partly, because his observations of the subsequent dilation of the affected pupil, and of certain inconsistencies when the incisions were made on both sides pointed to other sources of innervation of the dilator muscle of the pupil. This concurred with what

70 Ibid., p. 9, '. . . la prunelle s'est toujoûrs trouvée plus petite du côté de l'opération.' 


\section{A. E. Best}

he had learned anatomically, namely that the ciliary ganglion also received roots from the nasociliary and oculomotor nerves. Also, he rightly surmised that the ciliary nerves supplied sympathetic innervation to the blood vessels of the white of the eye, since the division of the cervical trunk of the sympathetic chain produced inflammation there.

His theoretical explanations must be judged mainly in the light of French, seventeenth-century mechanistic physiology. He argued that after the denervation of the blood vessels in the front of the eye they lost their elasticity ('ressort'), became more than normally distended with blood, and thus produced inflammation over the front of the eye..$^{80}$ But-his argument ran-as the blood pressure was partly absorbed through the distension of these flaccid vessels which were nearer to the surface, the circulation was reduced in the inner vessels which were still subject to the pressure of the sclera, so that the supply of humours to the inner compartments of the eye was reduced. The eyeball, he maintained, normally preserved its rotund shape through an equilibrium between the inward pressure of the sclera, which was reinforced by the backward tension of the rectus and oblique muscles, and the hydrostatic pressure of the humours, which was generated by the pressure of the supplying blood; as the blood vessels became relaxed ('relâchés'), there was a shift in the equilibrium, and a contraction and withdrawal of the eyeball [enophthalmos].81 An apparent dullness of the affected eye, he ascribed to the puckering of the fibres of the shrunken cornea. ${ }^{82}$

It would appear that he wished also to explain the accumulation of glutinous liquid in the front of the eye by the excess of blood in the distended vessels. But his explanation of why the lacrymal points ('points lacrymaux') failed to drain off this excess liquid is by no means clear. He had learned from the anatomical descriptions of Vieussens and others that the ophthalmic division of the fifth cranial nerve supplied fibres to the medial angle of the eye, and, in accordance with his own hypothesis, these were accompanied by sympathetic fibres, but it is not apparent how he conceived the closure of the lacrymal ducts, except in terms of the engorgement of surrounding blood vessels.

As we have seen, du Petit ascribed the contraction of the pupil on either side to the failure of sympathetic nerves. But why did the pupils enlarge when the sympathetic trunk was cut on both sides? The enlargement, he maintained, was a motor response to the impairment of vision brought about by the puckering of the cornea: when the dog was cut on one side only, it was not aware of the visual defect in one eye, and the pupil remained temporarily contracted through sympathetic denervation; when, however, the cuts were made on both sides of the neck, the sight was affected in both eyes, and the pupils dilated as a corrective response. He claimed that he had seen confirmation of this in patients with cataract or amaurosis ('goutte sereine'). When the disease was in one eye, the pupil appeared to be normal, but when it was in both eyes the pupils were considerably enlarged: 'Among those who have come to consult me about a cataract, which had formed in one eye, some have assured

${ }^{80}$ Ibid., pp. $13 f f$.

81 Ibid.

82 Ibid., p. 15, 'D'ailleurs de froncement ne peut se faire, qu'il ne se forme sur la superficie de la cornée des inégalités qui produisent des élévations et des enfoncements, qui tout imperceptibles qu'ils sont, ne laissent pas être réels.' 


\section{Pourfour du Petit's Experiments on the Origin of the Sympathetic Nerve}

me that it was only by chance that they became aware of the defective sight of that eye; they always thought that they were seeing with two eyes. ${ }^{\prime 83}$ This, for du Petit, was evidence that the dilator muscle of the pupil was innervated by other motor fibres besides sympathetic ones, and he shrewdly observed that, since in the case of the nictitating membrane, sympathetic denervation was followed by an almost permanent encroachment of the membrane, the withdrawal of the membrane into the medial angle must be due entirely to sympathetic innervation. ${ }^{84}$

\section{A NOTE ON THE RELATION BETWEEN DU PETIT AND MOLINELLI}

About thirty years after du Petit had published the results of his research, the Italian physician and scientist, P. P. Molinelli, wrote a short work entitled 'De ligatis sectisque nervis octavi paris', which appeared in the 1755 issue of De Bononiensi scientiarum et artium commentarii (vol. 3, pp. 280ff). Here he described the syndromes which followed upon the ligation and section of the trunk of the vagus nerve (i) on the left side, (ii) on the right side, and (iii) on both sides in the necks of dogs. He observed the effects in the eyes as well as the failure of the voice, quickened and irregular heart-beats and impaired respiration, a tendency to nausea, difficulty in swallowing, constipation, trembling limbs and general debility. His observations were of dogs in which the vagus, 'where it ran directly to the pharynx', had been laid open and bound tightly with two adjacent ligatures of waxed threads: ' . . nervum sinistrum octavi paris in collo patefeci, qua ad laryngem recta fertur, eumque filo cera obducto duobus in locis haud multum inter se dissitis valide obligavi ... (p. 281).

The syndromes which he saw in the eyes shortly after tying the threads were much the same as those described by du Petit in his paper of 1727. These included-in the eye of the affected side-dullness, inflammation of the conjunctiva, extension of the nictitating membrane over the cornea, discharge of tears, contraction of the pupil and retraction of the eyeball. As well as these, however, which had been observed already by du Petit, he described other effects, namely, a partial change in the colour of the iris (pp. 281, 285, 286), a distortion of the circular shape of the pupil (pp. 281, 286), and a failure, as in a squint, of the muscular control of the movement of the eyeball: 'Oculum sursum conversum habebat, ad externum angulum, quasi immobiliter, ut strabismo teneri videretur.' (p. 287).

On untying the threads which had been bound round the vagus, he observed that there was a return to normality generally, though some of the syndromes in the affected eye still remained: 'Oculo nitor suus redierat, nisi quod bulbi motus aliquanto adhuc erat tardior. Ad hoc corneam membrana cartilaginea ex parte obtegebat; pupilla in eodem oculo angustior, quam in dextero; iris, qua parte angulum externum spectat, coloris caerulei; quamvis et ipsa alibi per totum, et in dexero oculo tota coloris esset ad flavum vergentis ...' (p. 281).

In each case he dissected the dead animal and described how the previously constricted nerves had become considerably swollen above the place occupied by the upper ligature before its removal and below that occupied by the lower ligature. He opened the nerves at these swellings and described, though rather obscurely, a

sa Ibid., p. 18. 


\section{A. E. Best}

cellular structure and liquid content. To his credit, he had observed a few unsuspected syndromes of the eye, and some of them were confirmed by later experimenters. The late eighteenth-century Justus Arnemann observed the change of colour of the iris(!), and the mid-nineteenth-century Serafino Biffi the distortions of the pupil, as effects which followed upon the ligation of the sympathetic trunk in the neck; instead of dilating or contracting symmetrically when stimulated, the pupil would undergo irregularities in shape: 'Un minimo cambiamento di luce, una semplice impressione di terrore, bastano a provocare quella irregolarità di figura.' (Biffi, S., Opere Complete del S. B., Milan, 1902, vol. 1, pp. 1-10).

Molinelli was primarily interested in the theories of Friedrich Hoffmann (1660 1742), who held that bodily movement was brought about by the transmission of an ethereal substance whose flow was regulated by a kind of systole-diastole action of the meninges of the brain. Essential to this theory was the assumption that the nerve consisted of distensible fibres, and Molinelli believed that he had confirmed this structure by the swellings produced in the nerves by ligation. (Biographisches Lexikon der hervorragenden Ärzte, Berlin and Vienna, 1932, vol. 4, p. 233.) Accordingly, Molinelli's admirable research cannot be judged as making any sizeable contribution to the study inaugurated by du Petit concerning the origin of the sympathetic ("intercostal') nerve. Certainly, Molinelli was aware of the association of the vagus and the sympathetic ('intercostal') in the neck of the dog-'Nervi octavi paris . . . qui in collo intime cum intercostalibus conjunguntur . . . But he performed his experiments, as explained in the title of the paper, specifically to investigate the syndromes in relation to the changes which occurred in the vagus after the ligation of this nerve. He claimed that others, including du Petit, had paid no attention to these changes in the nerves: 'Alterationes, quae nervis ipsis accidunt, ubi vel secti, vel ligati, constrictive tantum sint, nemo fere attigit.' (P. P. Molinelli, op. cit., p. 280.)

The real point of du Petit's research was to refute certain false assumptions concerning the origin of the sympathetic ('intercostal') nerve, and he used the effects in the eyes for this purpose. What he deduced was an important contribution to a topic that was resumed by a succession of workers in the mid-nineteenth century culminating in the discoveries of Ruithe, Waller, Budge and Bernard. In other words, du Petit's work belonged to an historic line of inquiry which Molinelli, in fact, side-stepped. 